\title{
Design Of A Tractor Operated Dry - Season Sorghum (MASAKWA) Transplanting Machine
}

\author{
Balami, A. A., Dada, M. M. and Mohammed, I. A. \\ Department of Agricultural and Bioresources Engineering, \\ Federal University of Technology, Minna, Niger State, Nigeria
}

\begin{abstract}
The problems with the production processes of dry season sorghum (Masakwa) are low output due to the use of strenuous traditional tool, extension of transplanting period due to complete absence of modern machinery, non-uniformity of transplanting depth and plant spacing, and lack of water due to the proximity of the farm land to source of water. In view of that, a tractor operated dry- season sorghum transplanter was designed and analyzed using SOLIDWORKS 2011 and MATLAB 2009b as modeling aid. At a working speed of $7 \mathrm{~m} / \mathrm{s}$, the designed machine can transplant a hectare of land in 3 hour 38 minutes which is $52 \%$ more as compared with the modified manually operated dibble - 40\% (which makes and fill 10,000 holes in 42 hours i.e. 5 to 6 days at 8 hours/day) and the traditional dibble which transplant a hectare in $60-80$ hours (i.e. 8 - 10 days). N88, 870 (USD\$570) will be required to construct the machine.
\end{abstract}

Keywords: Masakwa, vertisol, dibble, solidworks, performance analysis

\section{INTRODUCTION}

Sorghum (Sorghum bicolor L. Moench) is the fifth most important cereal crop in the world and second to maize in Africa (FAO, 1996). It is widely grown in the subtropics, tropics and Africa continent. Of all Sorghum cultivars available for cultivation by farmers "Masakwa" the Dry Season - Sorghum has occupied an important position for some time in the region. This cereal crop is grows very well on Vertisol (30 - 60\% clay), heavy and light alluviums, red, gray, yellow loams and sandy soil (Pannar Seed, 2008). However, the crop is adapted to a wide range of soils provided its fertility is reasonable. Good yield may also be derived on soils with a pH of $4.5-7.5$ and it can withstand a certain amount of salinity (Pannar - Seed, 2008). This variety of sorghum (Fig. 1) is a short day, low temperature $\left(15-30{ }^{\circ} \mathrm{C}\right)$ and cold night cultivator. It is grown during the dry and cold harmattan period.

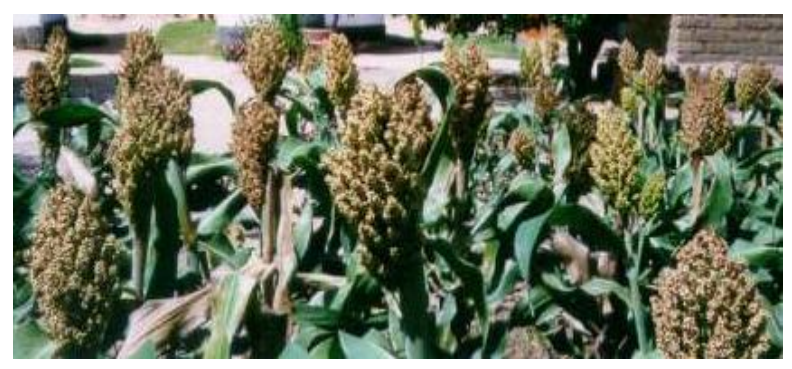

Fig. 1: Masakwa Sorghum plant

The dry-season Sorghum Producing Areas in Some Parts of the World are shown in Table 1.

Table 1: Dry-season Sorghum Producing Areas in Some Parts of the World

\begin{tabular}{lll}
\hline S/No. & Race of Sorghum & Regions/Country \\
\hline 1 & Sorghum bicolor race Bicolor & Nigeria, Uganda and Southwest Ethiopia \\
2 & Sorghum bicolor race Caudatum & Northeast Nigeria and Southwest Ethiopia \\
3 & Sorghum bicolor race Durra & India and North Africa \\
4 & Sorghum bicolor race Guinea & Sahelian west Africa \\
5 & Sorghum bicolor race Kafir & Eastern Africa, Southern Africa and Northern Nigeria \\
\hline
\end{tabular}


IOSR Journal of Engineering

Jan. 2012, Vol. 2(x) pp: xxx-Xxx

The major areas of cultivation in Borno State, Nigeria, are between Lake Chad in the north and part of Mandara hills in the south. Other areas in Borno State, Nigeria, include Dikwa, Bama, Ngala, Gwoza, Mungono and Marte Local Government Areas. In his areas cultivation state is by small scale peasant farmers (Olabanji et. al, 1996). Other locations in Borno State are contained in Table 2.1. Masakwa or Firgi sorghum is drought and cold tolerant short day sorghum cultivar that has been cultivated in the Lake Chad over centuries (Zach et. al; 1996). It is grown under residual moisture in vertisols of northeastern Nigeria during the harmattan period (Ogunlela and Obilana, 1983; Akposae. et. al, 1986; Olabanji. et. al, 1996; Zach et. al, 1996; Gworgwor, 2001 and Tabo, et. al, 2002). The total area under cultivation in the Lake Chad basin area of Nigeria is $102,584 \mathrm{Km}^{2}$ (Olabanji, et. al; 1996). The crop is also cultivated in northern parts of Cameroon and in the Chad Republic (Djonnewa and Dangi, 1988). Table 2 and 3 show the comparative yield of rain fed sorghum and dry-season sorghum in the north province and extreme north province of Cameroon and Borno State, Nigeria.

Table 2: Sorghum grown in the two northern province of Cameroon (Henk and Maurice, 2005)

\begin{tabular}{llc}
\hline Type of Sorghum & North Province (tones) & Extreme North Province (tones) \\
\hline Rain fed Sorghum & 190,000 & 325,000 \\
Dry season Sorghum & 22,000 & 150,000 \\
Total & $\mathbf{2 1 2 , 0 0 0}$ & $\mathbf{4 7 5 , 0 0 0}$ \\
\hline
\end{tabular}

Table 3: Dry season sorghum (Masakwa) producing areas, under cultivation in Borno State

\begin{tabular}{|c|c|c|c|c|c|}
\hline $\mathrm{S} / \mathrm{N}$ & L.G.A & Land area $\left(\mathrm{km}^{2}\right)$ & $\begin{array}{l}\text { Total cultivable } \\
\text { land }\left(\mathrm{km}^{2}\right)\end{array}$ & $\begin{array}{l}\text { Firgi land } \\
(\mathrm{Ha})\end{array}$ & $\begin{array}{l}\text { Actual Firgi } \text { under } \\
\text { cultivation(Ha) }\end{array}$ \\
\hline 1 & Dikwa & 1,683 & 37026 & 29,620 & 5,924 \\
\hline 2 & Ngala & 3,729 & 82039 & 73,834 & 11,075 \\
\hline 3 & Monguno & 3,926 & 86372 & 43,186 & 4,319 \\
\hline 4 & Kukawa & 6,710 & 147620 & 14,762 & 2,214 \\
\hline 5 & Bama & 6,175 & 135850 & 108,680 & 16,302 \\
\hline \multirow[t]{2}{*}{6} & Gwoza & 2,689 & 59158 & 118,32 & 1,775 \\
\hline & Total & & & 411,915 & 41,609 \\
\hline
\end{tabular}

relative short growth cycle allows it to develop and mature on the available residual soil moisture on the rather heavy deep vertisol (Black cotton soils). It is cultivated on land mass of 42,915 hectares in Borno state of Nigeria (Balami and Zanna, 2005). The yield is from 0.6 to 0.8 t/ha (Nwaka, 1989), which can be compared to the yield of wet season sorghum (0.8 - 1.0 t/ha) (Obilana, 1983).

The crop provides $40-80 \%$ of cereal to the people and is mainly used as food and for preparation of local liquor, etc (Djonnewa and Dangi, 1988). It also provides supplementary supply of grains and forage during the dry season for both human and livestock consumption (Ogunlela and Obilana, 1983) in the drier land marginal rainfall areas of the semi-arid tropics. It is also processed into flour used in the preparation of Tuwo, Porridge, Pap and other local delicacies (Zach et. al, 1996).

Though there is a modified dibbler (operated manually and $40 \%$ efficient), Masakwa production in Nigeria is still done manually i.e. the Masakwa seedlings are grown in small plots on well drained soil between August and September and are then transplanted (into holes made by a wooden instrument called dibble Fig.2) after five or six weeks in late September and October. No tillage operation is carried out before or after transplanting the seedlings. Usually manure or fertilizer is applied to the field before, during or after transplanting the seedlings. About $8 \mathrm{~kg}$ of seeds are required to transplant one hectare of land (BOSADP, 1993). 
IOSR Journal of Engineering

Jan. 2012, Vol. 2(x) pp: xxx-xxx

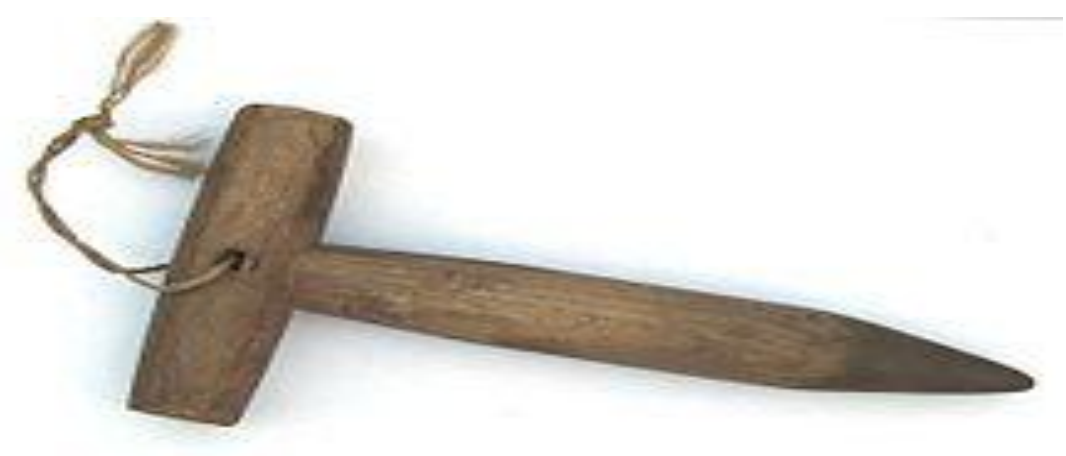

Fig 2: A Dibble

However, the major problem that could be identified in Masakwa production process are: low output due to the use of strenuous traditional tool, extension of transplanting period due to complete absence of modern machinery, non-uniformity of transplanting depth and plant spacing, and lack of water due to the proximity of the farm land to source of water.

Therefore, for these problems to be solved, Masakwa production must be mechanized, that is to design, simulate and model a tractor operated dry- season sorghum transplanter which will at the same time make holes for transplanting and apply water to the holes in precision.

\section{Agronomic Consideration}

\section{METHODOLOGY}

The basic agronomic information required for the design modification of the Dibble for Masakwa transplanting (Smekhounov, 1998) is as follows:

i. $\quad$ Distance between two adjacent rows and successive plant in row (i. e. inter and intra row spacing), which is 1.0 meters (Zach et al., 1996)

ii. Allowable plant deviation from the axis of the row, which is $\pm 0.2 \mathrm{~m}$ (Gworgwor)

iii. Transplanting depth, which is $0.2 \mathrm{~m}(20 \mathrm{~cm})$ (Zach et al., 1996)

iv. $\quad$ Diameter of hole, which is $5-6 \mathrm{~cm}$ (Zach et al., 1996)

v. Quantity of water required in each hole. Usually about $2 / 3$ of the hole is being filled with water (Haque and Audu, 1998)

The volume of water occupied by the hole is gotten as:

$$
\frac{\pi \times d^{2} \times h}{12}
$$

Where: $\mathrm{h}=$ height of the hole made by dibble, $\mathrm{d}=$ Diameter of the hole made by dibble

\section{Analytical Design Criteria}

The design of the tractor operated dry sorghum transplanting machine was based on the range of measurement values of the traditional Dibble. According to Haque and Audu (1998), Olabanji (1992), and Ogunlela and Obilana (1983) the height of convenient holding position, the transplanting depth and diameter at the soil are taken as $1200 \mathrm{~mm}, 200 \mathrm{~mm}$ and $60 \mathrm{~mm}$ respectively as optimum. Also the quantity of water poured into the hole is about $100-200 \mathrm{ml}$ (Haque and Audu, 1998) and about 2-3 handfuls (Ogunlela and Obilana, 1983). A water application and regulating device was also incorporated to facilitate the transplanting process. The pressure needed to penetrate the soil must be greater than the pressure of the vertisol i.e. $\mathrm{Pa}>\mathrm{Pv}$.

\section{Standard parameters}

The selection of this set of parameters is based on the type of tractor which the implement will be attached through the Three Point Linkage (TPL). Therefore a Massey Ferguson MF 260 of $60 \mathrm{hp}$ diesel tractor of category 1 and the standard dimensions for the hitch were taken from the ASABE S217.12 DEC01 (ASABE ISO+730-1:1994). 


\section{Functional Requirements}

The machine consists of the following components: Hollow square beam, Cylinder, Piston, Connecting rod, Actuator, Actuator support, Water tank (663 liters and has a weight of $650 \mathrm{Kg}$ ), Gusset plate, Dibble (9 in numbers), and Pipe. The machine has an area of $5 \mathrm{~m}^{2}$ with area having dibble as $4 \mathrm{~m}^{2}$,

\section{Material Selection}

The materials selected for each of the component are based on their strength, ability to withstand environmental conditions and their economy (Ashby, 2000).

\section{Stress Analysis}

The plates which are to be attached to the three point linkage are analyzed with SOLIDWORKS 2011 based on the weight of the implement when the water tank is filled which $7.93 \mathrm{kN}$. Plain carbon steel was selected based on the stress and strain result using Von-Mises stress with 2916 Jacobian point mesh (Shigley and Mischke, 1996 and David, 2004). The solid mesh and its static strain and stress analysis are shown in Fig. 3.

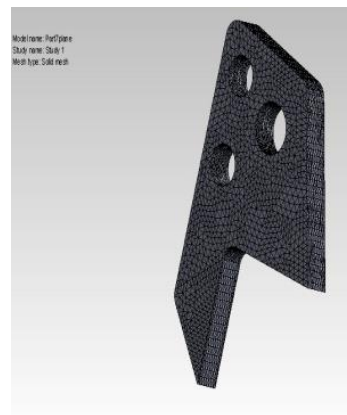

a)

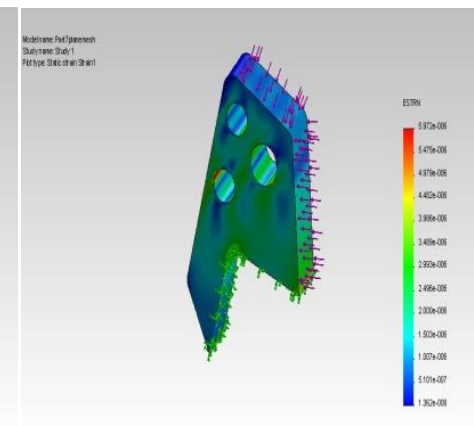

b)

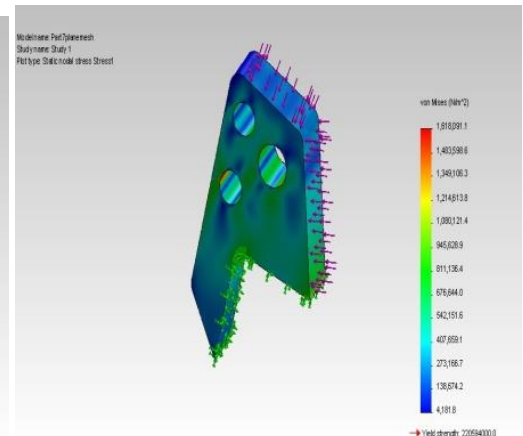

c)

Fig 3: a - solid mesh of plate, $\mathrm{b}$ - static strain analysis of the gusset plate, $\mathrm{c}$ - static stress analysis of the gusset plate

In carrying out the stress and strain analysis, the plate dimensions and material properties were changed several times to make sure it can withstand the applied stress and strain which will carry the applied weight of the implement. The analysis of the plate was carried out by fixing the bottom curve of the plate and load equivalent to the weight of the implement being applied to the top and right side. The stress is analyzed using Von Mises stress analysis (David, 2004).

$$
\sigma_{e} \geq S_{y}
$$

Where: $\sigma_{e}$ - equivalent stress, $S_{y}$-the tensile yield strength,

\section{Principle of Operating of the transplanting machine:}

The machine is basically operated through the tractor three point linkages, with the help of two persons, one driving and operating the pump while the second put two seedlings into the holes.

The implement is connected to the tractor three point linkages through its connecting pins to keep it in place. At the start of the operation the implement is kept in a lift position and placed over the required position where the hole is to be made. The following sequence is carried out when making each set of holes.

i. $\quad$ Dropping of the implement to make the holes to the required depth.

ii. Slowly lifting the implement to about $20 \mathrm{~cm}$ above the hole - surface.

iii. Pumping the water contained in the cylinder through the actuator.

After pumping the required amount of water into the holes and the implement lifted and moved forward, then the role of the second person comes to play by putting two seedlings into the hole. The holes are not covered with soil after transplanting the seedlings.

The tractor was operated at a speed range of $1-7 \mathrm{~m} / \mathrm{s}$ and effective working time ranging from approximately $3.4-7$ hours while the water tank has to be filed twice to work a hectare of land (10,000 holes). 
IOSR Journal of Engineering

Jan. 2012, Vol. 2(x) pp: xxx-xxx

The 3D model with graphics of the machine is shown in fig. 4 .

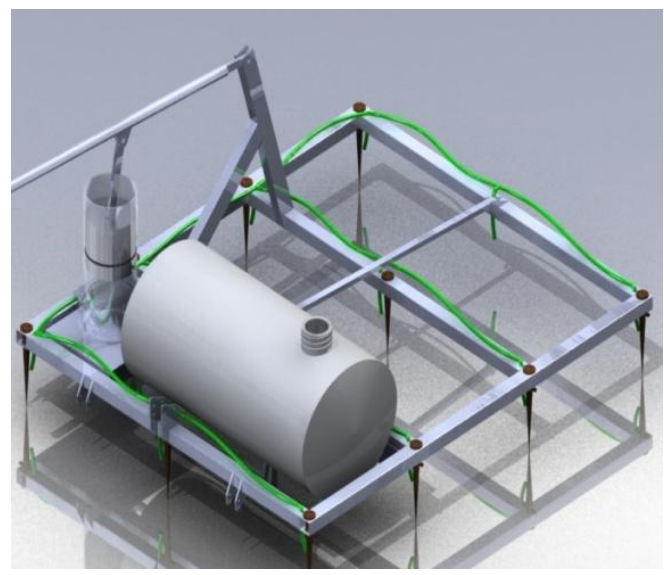

Fig 4: Full 3D model with graphics of the machine

\section{Efficiency}

The model was evaluated based on the data used in generating its model and measured variables from the tractor. The following computations were carried out based on the measurement from the tractor.

i. It takes approximately 8 seconds to drop and lift the three point link to its minimum and maximum respectively without stopping.

ii. The time taken by the tractor to travel a distance of $3 \mathrm{~m}$ was determined by varying the speed of the tractor from $1 \mathrm{Km} / \mathrm{h}$ to $7 \mathrm{Km} / \mathrm{h}$.

iii. From the force and discharge relation, it was deduced that a minimum of 5 seconds is taken to discharge $126 \mathrm{ml}$ of water into the holes.

Based on the above measurements and taking it as a cycle time, it was found that it took a total of 11 - 22 seconds to perform one circle. In a hectare, there are 10,000 holes of 1 meter equidistance, at low plant density to reduce risk of water stress and produce bigger panicle (Olabanji, 1992). Taking into cognizance the dimension of the machine part that makes the holes which is $2 \times 2$ $\mathrm{m}$, making the area of the machine $4 \mathrm{~m}^{2}$. Using the area of the machine, the number of sets made by the machine per drop and other computation is found to be (for ease of computation, variables were assigned to different requirements).

After simulating the planting operation, a time frame of $3-7$ hours was found to be the total time it will take the machine to transplant a hectare of land when attached to the tractor. This time gave an efficiency ranging from $90-94 \%$ over the wooden dibble and $83-92 \%$ over the modified dibble. The short time in recorded was mainly due to the number of dibbles used and also because it was operated by a tractor.

\section{Economic analysis}

The cost analysis of the machine shows that total of N88, 870 (USD\$570) will be required to construct the machine. By using this cost, an economic analysis was carried out and it shows that the lifetime worth (LTW) of the machine after five year is considerably high at N602, 199. The LTW portrayed that the machine will still be effective even after five years.

\section{DISCUSSION OF RESULTS}

The test result of the proposed transplanting machine is presented in Table 3.

Table 3: Test result of proposed transplanting machine

\begin{tabular}{|c|c|c|c|c|}
\hline \multirow{2}{*}{ Speed, $\mathrm{m} / \mathrm{s}$} & \multicolumn{4}{|c|}{ Parameters } \\
\cline { 2 - 5 } & $\mathrm{T}_{\text {circle }}, \mathrm{s}$ & $\mathrm{N}_{\text {droppings, }}$ & $\mathrm{N}_{\text {d.hour }}$ & $\mathrm{T}_{\text {hectare, }}, \mathrm{hr}$ \\
\hline 1 & 22.64 & 159 & 1431 & 2.98 \\
\hline 2 & 15.82 & 227 & 2048 & 4.88 \\
\hline 3 & 13.54 & 265 & 2392 & 4.18 \\
\hline
\end{tabular}


IOSR Journal of Engineering

Jan. 2012, Vol. 2(x) pp: xxx-xxx

\begin{tabular}{|l|l|l|l|l|}
\hline 4 & 12.41 & 290 & 2611 & 3.83 \\
\hline 5 & 11.72 & 307 & 2763 & 3.62 \\
\hline 6 & 11.27 & 319 & 2874 & 3.48 \\
\hline 7 & 10.95 & 329 & 2959 & 3.38 \\
\hline
\end{tabular}

The proposed transplanting machine working at a speed of $7 \mathrm{~m} / \mathrm{s}$ can transplant a hectare of land in 3 hour 38 minutes which is $52 \%$ more as compared with the modified manually operated dibble - 40\% (which makes and fill 10,000 holes in 42 hours i.e. 5 to 6 days at 8 hours/day) and the traditional dibble which transplant a hectare in $60-80$ hours (i.e. $8-10$ days).

\section{CONCLUSION}

Using both agronomic and mechanical parameters a suitable design and graphical conceptual model of a tractor operated dry season sorghum transplanting machine was achieved. $52 \%$ efficiency was achieved over the use of the modified and traditional Dibble to make holes in the field to transplant dry season sorghum with reduced fatigue on the user.

\section{REFERENCE}

1. Akposae, K., Wudiri, B. B. and Sarpong, K. B (1986). Masakwa improvement in the Chad Basin NOMA 6:30-31.

2. ASABE (1994). Three-Point Free-Link Attachment for Hitching Implement to Agricultural Wheel Tractor. ASABE S217.17 DEC 01.

3. Ashby, M. F. (2000). Materials Selection in Mechanical Design. $2^{\text {nd }}$ Edition. Butterworth - Heinemann, Oxford, England.

4. Balami. A and Zanna. A. (2005). Modification and Performance Evaluation of a Dibble for Transplanting Dry Season Sorghum (Masakwa) Seedlings in Nigeria, Bulletin of Armenian Agricultural Academy, 4(12), pg 78-81.

5. Borno State Agricultural Development Programme (BOSADP) (1998). Package of Cropping Recommendation for Borno State pp.76.

6. David V. H. (2004). Fundermentals of Finite Element Analysis. McGraw - Hill Companies Inc. USA.

7. Djonnewa, A and Dangi, O. P. (1988). "Improvement of Transplanted Sorghum". In Proceedings of the Third Regional Sorghum Workshop, 20-23 Sept. 1988, Moroua. Cameroon, p.48-52.

8. FAO (1996). Part 1, Sorghum. The world Sorghum and Millet. Economics. Facts, Trends and Outlooks. Basic Food Stuffs Services of FAO and Socio-economic and Policy Division of ICRISAT. pp.5 - 27.

9. Gworgwor, N. A (2001). Masakwa Production in Borno State of Nigeria a Survey NOMA 11: pp.8-19.

10. Haque, M. A and Audu, I (1998), Current Pratices of Transplanting Dry-Season Sorghum in Borno State of Nigeria. Annals of Borno 15/16 (1998/1999), University of Maiduguri Press. pp. 254-57.

11. Henk. K and Maurice. K. (2005). The Potential for Developing a Sorghum Supply Chain for Guiness Cameroun S. A, I a Rapid Assessment March 29 - April 5. 2005, Pg 4\&5.

12. Nwaka, G. I. C. (1989). "Morphological Characteristics, Classification and Management of some Vertisols in Nigeria", in: "Vertisol Management in Africa", proceedings of a workshop held at Univ. of Zimbabwe, Harare, 16-21 Jan. 1989. (IBSRAM proceedings No.9, p.362-381).

13. Obilana, A. T. (1983). Status of Sorghum Research towards better and Increased Productivity, Proceeding of $1^{\text {st }}$ Joint National Workshop of NAFPP 10-15 Jan. 1983, Ibadan, Nigeria.

14. Ogunlela, V. B and Obilana, A. T. (1983). Masakwa: The Harmattan Sorghum in Nigeria NOMA News Magazine, I. A. R., A. B. U. Zaria, 4(1). 1 May 1983, p. $4-6$.

15. Olabanji, O. G. (1992). Rising of Masakwa and Transplanting of seedlings, Lake Chard Research Institute. Maiduguri, Nigeria.

16. Olabanji, O.G, Tabo. R, Flower. D. J. Ajayi. O, Ushie. F, Kaigama. B. k, and Ikwelle. M. C. (1996). Production and Management, Survey of Masakwa Sorghum Growing Areas in Northeastern Nigeria, Publication of Lake Chad Research Institute and ICRISAT. 1996. ISMN 3761-63.

17. Pannar-Seed, (2008). Sorghum Production Guide Series, Pannar Seed (PTY) LTD.

18. Shigley Joseph and Michke Charles. (1996), Standard Handbook of Machine Design, $2^{\text {nd }}$ ed., McGraw-Hill. New York.

19. Smekhounov, E. (1998). "Methodical Aspects of Mechanization process of Masakwa Transplanting". Annals of Borno 15/16 (1998 -.1999). University of Maiduguri Press (pp $341-347)$.

20. Tabo, R., Olabanji, O. G., Ajayi, O. and Flower, D. J. (2002). Effect of Plant Population on the Growth and Yield of Sorghum Variet.ies Grown on Vertisol(s). African Crop Science Journal Vol. 10(1) 31-38.

21. Zach, B., Kirsht, H. and Ohr, D., (1996). Masakwa Dry Season Cropping in the Chad Basin. Berichte de Soriderfo Rschungsbereichs 268, Band 8, Frankfurt-9m, 349 - 356pp. 